\title{
PENDEKATAN KUALITATIF
}

\section{PARADIGMA, EPISTIMOLOGI, TEORI DAN APLIKASI}

\author{
Atim Syaiful Bakhri \\ Yusuf Rizal Hanubun \\ Sekolah Tinggi Agama Islam Negeri (STAIN) Sorong \\ Email : Atimsyaiful@Gmail.com dan Yusufrizalhanubun@gmail.com
}

\section{Pendekatan Kualitatif}

Obyek dan masalah penelitian mempengaruhi pertimbangan-pertimbangan mengenai pendekatan, desain ataupun metode penelitian yang akan diterapkan. Tidak semua obyek dan masalah penelitian bisa didekati dengan pendekatan tunggal, sehingga diperlukan pemahaman pendekatan lain yang berbeda agar begitu obyek dan masalah yang akan diteliti tidak pas atau kurang sempurna dengan satu pendekatan maka pendekatan lain dapat digunakan, atau bahkan mungkin menggabungkannya.

Sebagaimana diungkapkan diatas bahwa secara umum pendekatan penelitian atau sering juga disebut paradigma penelitian yang cukup dominan adalah paradigma penelitian kuantitatif dan penelitian kualitatif. Penelitian kualitatif adalah suatu penelitian yang ditujukan untuk mendeskripsikan dan menganalisis fenomena, peristiwa, aktivitas sosial, sikap, kepercayaan, persepsi, pemikiran orang secara individual maupun kelompok. Beberapa deskripsi digunakan untuk menemukan prinsip-prinsip dan penjelasan yang mengarah pada penarikan kesimpulan. Menurut Sukmadinata Penelitian kualitatif bersifat induktif, peneliti membiarkan permasalahanpermasalahan muncul dari data atau dibiarkan terbuka untuk interpretasi. Data dihimpun dengan pengamatan yang seksama, mencakup deskripsi dalam konteks yang mendetail disertai catatancatatan hasil wawancara yang mendalam, serta hasil analisis dokumen dan catatan-catatan. 
Penelitian kualitatif mempunyai dua tujuan utama, yaitu: 1) menggambarkan dan mengungkapkan (to descibe and explore) dan 2) menggambarkan dan menjelaskan (to describe and explain). Berdasarkan tujuan yang ingin dicapai itulah maka penelitian kualitatif menggunakan instrumen pengumpulan data yang sesuai dengan tujuannya (Bachtiar S. Bachri, 2010).

Dengan orientasi yang memiliki tujuan diatas, maka penelitian kualitatif memiliki paradigma sebagaimana yang diungkapkan Lincoln dan Guba yang dikutip Alwasilah (2008) yakni:

1. Natural setting (latar tempat dan waktu penelitian yang alamiah).

2. Humans as primary data-gathering instrumens (manusia atau peneliti sendiri sebagai instrumen pengumpul data primer).

3. Use of tacit knowledge (penggunaan pengetahuan yang tidak eksplisit).

4. Qualitative methods (metode kualitatif).

5. Purposive sampling (pemilihan sampel secara purposif).

6. Inductive data analysis (analisis data secara induktif atau bottom-up).

7. Grounded theory (teori dari dasar yang dilandaskan pada data secara terus menerus).

8. Emergent design (cetakbiru penelitian yang mencuat dengan sendirinya).

9. Negotiated outcomes (hasil penelitian yang disepakati oleh peneliti dan responden).

10. Case-study reporting modes (cara pelaporan penelitian gaya studi kasus).

11. Idiographic interpretation (tafsir idiografik atau kontekstual).

12. Tentative application of findings (penerapan tentatif dari hasil penelitian).

13. Focus determined boundaries (batas dan cakupan penelitian ditentukan oleh fokus penelitian).

14. Special criteria for trustwortginess (mengikuti kriteria khusus untuk menentukan keterpercayaan dan mutu penelitian).

Berdasarkan karakteristik yang merupakan paradigma tersebut maka penelitian kualitatif memiliki "jalan" tersendiri dalam menemukan jawaban atas masalah penelitiannya. Jawab yang diberikanpun bersifat unik dan spesifik pada subjek tertentu. Hal ini dikarenakan tujuan penelitian kualitatif justru menemukan teori dan bukan sekedar verifikasi dari teori yang sudah 
ditemukan, sehingga penarikan kesimpulan hanya diberlakukan pada subjek tersebut dan tidak digeneralisasikan.

\section{A. Paradigma}

Semua disiplin penelitian dilakukan dalam sebuah paradigma.Paradigma penelitian dipahami sebagai keyakinan dasar di mana teori akan di bangun, yang secara fundamental mempengaruhi bagaimana peneliti melihat dunia dan menentukan perspektif dan bentuk pemahaman tentang bagaimana hal-hal yang saling terkait (Ihwan Susila, 2015).

Secara umum pendekatan penelitian atau sering juga disebut paradigma penelitian yang cukup dominan adalah paradigma penelitian kuantitatif dan penelitian kualitatif. Dari segi peristilahan para ahli nampak menggunakan istilah atau penamaan yang berbeda-beda meskipun mengacu pada hal yang sama. Secara konsep, paradigma adalah asumsi-asumsi dasar yang diyakini ilmuwan dan menentukan cara dia memandang gejala yang ditelaahnya. Ia dapat meliputi kode etik, maupun pandangan dunia, yang mempengaruhi jalan pikiran dan perilaku ilmuwan dalam berolah ilmu (Sulaiman, 2018). Menurut Ritzer, paradigma membantu merumuskan tentang apa dan bagaimana persoalan harus dipelajari dan mesti dijawab (George Ritzer, 2009)

Menurut Creswell, 1998 dalam Emzir 2010, alasan seseorang melakukan penelitian kualitatif antara lain: karena hakikat dari pertanyaan penelitian. Dalam studi kualitatif, pertanyaan penelitian sering dimulai dengan bagaimana atau apa. Dengan demikian, permulaan tersebut memaksa masuk kedalam topik yang mendeskripsikan apa yang sedang berlangsung. Penelitian interpretip tidak mendefinisikan variabel dependen dan indepennt, tetapi fokus hanya pada kompleksitas perilaku manusia yang muncul (Emzir, 2010).

Sejak dari Thomas Kuhn kemudian berkembang. Menurut Masterman, Kuhn menggunakan konsep paradigma sekurang-kurangnya dalam 21 cara yang berlainan. Paradigma menggolongkan, menetapkan, dan menghubungkan eksamplar, teori, metode, dan instrumen yang ada di dalamnya. Menurut Kuhn, perjalanan dimulai dari paradigma lama pada normal sains, lalu dalam perjalannya muncul anomali, yang kemudian melahirkan krisis, lalu terjadi revolusi sains, hingga muncul teori baru.

Penggunaan paradigma dalam perkembangannya berlangsung secara berbeda. Konsep ini 
bisa tidak konsisten, sehingga dalam berbagai keterangan berubah konteks dan arti. Menurut Bryman, dialektika berlangsung dari Kuhn, Guba dan Lincoln, hingga Ritzer. Kuhn dipandang sebagai titik awal ide tentang paradigma, yang memberi pengaruh dalam perkembangan ilmu pengetahuan. Dengan ide Kuhn, Guba dan Lincoln kemudian mempertajam dalam menuju penelitian baik kualitatif dan kuantitatif (Sulaiman, 2018).

Ada dua pandangan besar dalam kegiatan penelitian yang menyangkut metode yaitu pandangan positivistik dan non positivistik. Dalam paham positivistik, segala sesuatu atau gejala itu dapat diukur secara positif atau pasti sehingga dapat dikuantifikasikan. Hal tersebut tidak hanya berlaku dalam ilmu alam saja, tetapi juga pada ilmu sosial. Dalam ilmu alam, paham positivistik tersebut tidak banyak menemui kendala karena objeknya adalah materi atau benda. Tetapi ketika diterapkan pada ilmu sosial, maka bukan saja sulit dilakukan, tetapi juga banyak ditentang oleh ilmuwan-ilmuwan sosial. Penganut paham positivistik tersebut berpendapat bahwa segala sesuatu itu tidak boleh melebihi fakta. Dalam paham non-positivistik, kebenaran tidak hanya berhenti pada fakta, melainkan apa makna di balik fakta tersebut. Dalam ilmu sosial, di mana kajiannya adalah manusia bukannya benda, maka pandangannya lebih didominasi oleh pandangan non-positivistik. Dalam konsepsi ini, paham positivistik diidentifikasikan dengan kegiatan riset kuantitatif, sedangkan paham non-positivistik diidentifikasikan sebagai kegiatan riset kualitatif. Namun demikian, perbedaan paham tersebut berdampak positif terutama dijadikan sebagai ajang dialog dalam rangka untuk mengembangkan keilmuan baik sosial maupun alam, untuk saling melengkapi kedua paradigma tersebut.

Pada awal perkembangan riset kualitatif, terjadi pertentangan yang sangat tajam dengan riset kuantitatif, yang sebelumnya secara kuat telah menguasai kegiatan penelitian di segala bidang ilmu. Pada mulanya riset kualitatif dipandang sebagai kegiatan yang tidak bisa dipercaya dan dipandang tidak ilmiah. Perdebatan panjang dan saling menyerang telah terjadi dalam waktu yang cukup lama. Dengan menunjukkan kekuatanya masing-masing, pertentangan tersebut telah berkembang dan mendudukkan posisi penelitian kualitatif menjadi berbeda, yaitu sebagai pendekatan yang diakui oleh sebagian besar pakar penelitian dan para ilmuan sebagai suatu alternatif metodologi penelitian yang bisa digunakan. Pada saat ini kedua paradigma penelitian tersebut telah dinyatakan sama kedudukannya, dan bahkan bisa saling membantu untuk memperkuat hasil penelitian. Perdebatan secara resmi sudah tidak lagi terdapat pada artikel jurnal penelitian di dunia. Perdebatan sudah dipandang berakhir. Namun banyak yang 
menyayangkan berakhirnya perdebatan tersebut, karena ternyata perdebatan tersebut mempunyai dampak positif terutama dalam meningkatkan kemantapan paradigma penelitian kualitatif.

Dalam menanggapi perkembangan pengetahuan manusia, Auguste Comte sebagai tokoh positivisme telah merumuskan adanya tiga jaman yaitu jaman teologis, metafisis, dan positif. Dalam jaman teologis diyakini adanya kuasa adi kodrati yang mengatur gerak dan fungsi semua gejala alam ini. Kuasa tersebut berada pada tingkat yang lebih tinggi daripada makhluk insani. Jaman ini dinyatakan terbagi menjadi tiga periode yaitu animisme, politeisme, dan monoteisme. Pada jaman metafisis, kuasa adi kodrati tersebut telah digantikan dengan konsep-konsep abstrak, seperti halnya "kodrat", dan "penyebab".

Selanjutnya pada jaman positif, manusia telah membatasi diri pada fakta yang tersaji dan menetapkan hubungan antar fakta tersebut atas dasar observasi dan dengan menggunakan kemampuan rasionya. Atas dasar itu perkembangan ilmu pengetahuan juga terbagi menjadi tiga, yang pada awalnya bersifat teologis, kemudian berkembangan menjadi metafisis, dan selanjutnya dianggap mencapai kematangan positif. Jaman positif ini berkaitan dengan berkembangnya faham positifisme, yang menyatakan bahwa pengetahuan kita tidak boleh melebihi fakta, karena ilmu pengetahuan bersifat faktual.

Dilihat dari sejarah jaman keyakinan yang mendasari perkembangan ilmu menjelaskan bahwa jaman yang satu digantikan oleh jaman berikutnya, sebagai hasil perkembangan kesadaran manusia dengan pola pikirnya mengenai kenyataan yang ada di alam kehidupan manusia ini. Dalam kenyataan selanjutnya, sampai dengan saat ini perkembangan jaman tersebut tidak berakhir sampai pada positivisme, karena dewasa ini sudah berkembanga faham baru yang mulai meninggalkan positivisme dan menyajikan keyakinan dengan warna yang berbeda, dan memulai jaman baru yang disebut jaman pascapositivisme. Dengan demikian perkembangan jaman keilmuan dinyatakan terdiri dari tiga jaman yakni jaman prapositivisme, positivisme, dan pascapositivisme.

Perkembangan penelitian, baik dalam ilmu kealaman maupun ilmu sosial, selama ini telah melewati sejumlah jaman paradigma, dengan periode-periode dimana seperangkat kepercayaan dasar tertentu membimbing para peneliti dalam cara-cara yang sangat berbeda-beda. Setiap jaman (prapositivisme, positivisme, dan pascapositivisme) memiliki seperangkat keyakinan dasar yang unik, merupakan prinsip metefisis, yang harus dipercaya dan digunakan sebagai petunjuk bagi setiap aksi atau aktivitas. 
Penelitian kualitatif pada hakikatnya lebih menekankan pada penggunaan diri si peneliti sebagai instrumen. Lincoln dan Guba mengemukakan bahwa dalam pendekatan kualitatif peneliti seyogianya memanfaatkan diri sebagai instrumen, karena instrumen nonmanusia sulit digunakan secara luwes untuk menangkap berbagai realitas dan interaksi yang terjadi. Peneliti harus mampu mengungkap gejala sosial di lapangan dengan mengerahkan segenap fungsi inderawinya. Dengan demikian, peneliti harus dapat diterima oleh informan dan lingkungannya agar mampu mengungkap data yang tersembunyi melalui bahasa tutur, bahasa tubuh, perilaku maupun ungkapan-ungkapan yang berkembang dalam dunia dan lingkungan informan (Mohammad Mulyadi, 2011).

\section{B. Epistimologi}

Methodologi penelitian merupakan ilmu yang mempelajari tentang metode-metode penelitian. Dilingkungan filsafat, logika dikenal sebagai ilmu tentang alat untuk mencapai kebenaran. Bila ditata dalam sistematika tertentu, methodology penelitian merupakan bagian dari logika ( Noeng Muhajir, 2009). Tujuan dari metodologi penelitian itu sendiri adalah untuk mengetahui gambaran mengenai keadaan (description of exiting reality) hubungan antara satu hal dengan yang lain, khususnya hubungan sebab akibat (causality). Penilaian mengenai hubungan antara bneberapa hal (relations of variable) akan menghasilkan kesimpulan umum (generalization) atau kecenderungan umum (general tendency).

Apabila mendekati kepastian akan menimbulkan penetapan suatu hukum. Pada umumnya metodologi pengetahuan mengandung unsure-unsur yang berhubungan secara berkesinambungan, yang membentuk sustu sistematika ilmu, sehingga menyebabkan ilmu pengetahuan bisa diterima keberadaannya. Ada tiga masalah yang membedakan satu pengetahuan dengan yang lainnya seperti perbedaan antara pengetahuan ilmiah dan pengetahuan agama, yaitu ontology, epistimologi dan aksiologi ( Dawam Rahajo, 2009). Dasar dari epistemologi dapat diketahui menggunakan pertanyaan-pertanyaan yang bermaksud menggali bagaimana pengetahuan tersebut diperoleh. Sedangkan pertanyaan aksiologi ingin mengungkapkan tentang maksud atau kegunaan dan makna dari pengetahuan tersebut. (Eki Suprawati, 2009)

Epistemologi berasal dari kata "Episteme" yaitu pengetahuan dan juga "logos yang bermakna ilmu, uraian atau alasan sehingga secara etimologi, epistemologi dapat diartikan sebagai teori tentang ilmu pengetahuan atau Theory of Knowledge.Epistemologi merupakan 
sebuah kajian ilmu yang sangat populer dan menjadi hal yang paling menarik. Secara sederhana Epistemologi merupakan pokok bahasan yang mengkaji tentang pengetahuan serta kaitannya dengan kebenaran yang hakiki. Epistemologi menjadi pembahasan menarik ketika dikaitkan dengan ketuhanan karena kebenaran yang hakiki hanya akan dimiliki oleh tuhan, oleh karena itu hakikat dari kebenaran hakiki yang dijadikan subjek dalam Epistemologi menjadi hal yang mustahil untuk didapatkan oleh pemikiran dan rasa dari manusia sebagai makhluk ciptaan tuhan. Seperti yang telah dijelaskan di atas, epistemologi adalah asumsi tentang landasan ilmu pengetahuan (grounds of knowledge) - tentang bagaimana seseorang memulai memahami dunia dan mengkomunikasikannya sebagai pengetahuan kepada orang lain. Bentuk pengetahuan apa yang bisa diperoleh? Bagaimana seseorang dapat membedakan apa yang disebut "benar" dan apa yang disebut "salah"? Apakah sifat ilmu pengetahuan? Pertanyaan dasar tentang epistemologi menekankan pada apakah mungkin untuk mengidentifikasikan dan mengkomunikasikan pengetahuan sebagai sesuatu yang keras, nyata dan berwujud (sehingga pengetahuan dapat dicapai) atau apakah pengetahuan itu lebih lunak, lebih subjektif, berdasarkan pengalaman dan wawasan dari sifat seseorang yang unik dan penting (sehingga pengetahuan adalah sesuatu yang harus dialami secara pribadi) (Chairil A, 2009).

Pembahasan metode penelitian lebih pada aspek epistimologi, yaitu cara memperoleh ilmu pengetahuan dengan metode ilmiah. Cara menyusun tubuh pengetahuan ini menurut Jujun, didasarkan pada:

1. Kerangka pemikiran yang bersifat logis dengan argumentasi yang bersifat konsisten dengan pengetahuan sebelumnya yang telah berhasil disusun.

2. Menjabarkan hipotesis yang merupakan deduksi dari kerangka pemikiran tersebut.

3. Melakukan verifikasi terhadap hipotesis untuk menguji kebenaran dan menyatakan secara factual ( Jujun Suriasumantri, 2010).

Epistimologi ilmu pengetahuan terdiri dari tiga bagian, yaitu: Observasi, deduksi dan induksi. Observasi merupakan upaya untuk melihat, mengamati dan mengevaluasi kenyataan yang ada, kemudian menetapkan asumsi, klasifikasi, abstraksi, hakikat, tipe, ideal dengan menunjukkan generalisasi. Observasi diperlukan sebagai bukti akan keberadaan suatu fenomena yang berhubungan erat dengan dengan aktivitas manusia. Sementara itu deduksi membicarakan 
cara-cara untuk mencapai kesimpulan-kesimpulan bila lebih dahulu telah diajukan pertanyaanpertantaan mengenai semua atau sejumlah ini diantara suatu kelompok sesuatu. Kesimpulan yang sah pada suatu penalaran deduktif selalu merupakan akibat yang bersifat keharusan dari pernyataan-pernyataan yang lebih dahulu diajukan. Sedangkan induksi membicarakan tentang penarikan kesimpulan dari pernyataan-pernyataan kusus. Kesimpulan hanya bersifat probabilitas berdasarkan atas pernyataan-pernyataan yang telah diajukan.

Musa Asy’arie menjelaskan bahwa hakikat dari epistemologi merupakan suatu usaha yang dilakukan untuk mencari hakikat dari sebuah ilmu. Usaha yang dilakukan dalam mencari kebenaran dari sekedar trial and error tetapi dilakukan secara sistematis dan disertai dengan metode-metode yang bersesuaian dengan objek dari kajian ilmu. Pada kajian ilmu pendidikan yang bersifat sains dapat disimpulkan bahwa fakat sains harus didapatkan dan dikaji melalui sebuah percobaan pengamatan dalam bentuk sains pula. Pendapat dari beberapa sumber yang tidak dapat dipertanggungjawabkan secara saintis tidak boleh dijadikan rujukan yang berlaku alas kebenaran dalam menjelaskan kejadian alam.

Sejarah mencatat bahwa alas agama telah menjadi alat yang digunakan oleh otoritas yang salah mengartikan ayat ilahi dan meletakkan pengartian mutlak pada pemuka agama tanpa didasari fakta sains. Galilei Galileo adalah salah satu ilmuwan terkemuka di Italia yang menjadi korban. Ia dihukum karena menemukan suatu kebenaran yang bertentangan dengan pandangan gereja mengenai alam semesta. Fakta ini mendukung bahwa kajian dari epistemologi sangat penting untuk menghindari kejadian di Italia sekitar 3 abad silam.

Epistemologi naturalistik-positivistik (lazim pula positivistik), "pendekatan sains atau pendekatan objektif', bersumber dari pemikiran Comte yang menegaskan bawa fenomena sosial, baik itu pengetahuan sosial maupun perilaku sosial, memiliki karakteristik yang sama dengan fenomena alam. Ada hukum umum yang mengatur tindakan manusia. Tugas para ilmuwan sosial adalah menemukan dan menjelaskan hukum-hukum umum. Karena kemiripan kedua fenomena ini, maka metode penelitian ilmu alam dapat dipakai untuk melakukan penelitian ilmu sosial. Klaim ilmiah hanya dapat dibuktikan kebenarannya lewat metode ilmu alam (science). (Anantawikrama Tungga Atmadja, 2013)

Lebih luas mengenai epistemologi, Dagobert D' Runes, seorang ahli filsafat dari Universitas Vienna menyatakan bahwa Hakikat dari Epistemologi merupakan upaya dalam mekaji sumber dari kebenaran atau ilmu secara structural. Metode yang digunakan dalam 
mengkaji kebenaran harus menggunakan metode yang valid sehingga hasil yang didapatkan dapat dipertanggungjawabkan secara ilmiah. Tujuan dari penjelasan ini merupakan upaya untuk menghindari kejadian yang bisa berakibat buruk pada peradaban manusia.

Masalah utama yang dihadapi dari kajian Epistemologi secara menyeluruh pada ilmu sains adalah bagaimana cara mengetahui pengetahuan secara hakiki. Jumlah disiplin ilmu yang sangat banyak dengan pendekatan yang banyak pula membuat kajian mengenai hakikat dari suatu obyek ilmu menjadi sangat susah dan membutuhkan pengabdian yang panjang hanya untuk mencari kebenaran yang jumlahnya setitik.

\section{Teori}

Teori dalam pendekatan kualitatif pada dasarnya ialah simbolik interaksionisme, etnometodologi, phenomenologik, kebudayaan dan lain sebagainya. Dimana para kualitan mengutamakan bukan teori yang pasti atau mapan, mereka berteori tentang fenomena-fenomena manusia dari aspek simbol, etnik, dan seterusnya. Sesuatu yang dapat saja berubah, bahkan ada aliran ekstrim yang kualitatif dengan meniadakan teori dalam penelitian (Lukas S musianto, 2009)

1. Simbolik Intereksionalisme

Awal perkembangan interaksi simbolik berasal dari dua aliran, Pertama, mahzab Chicago, yang dipelopori Herbert Blumer1 (1962), melanjutkan penelitian yang pernah dilakukan George Herbert Mead (1863-1931). Blumer meyakini bahwa studi manusia tidak bisa dilakukan dengan cara sama seperti penelitian pada benda mati. Seorang peneliti harus empati pada pokok materi, terjun langsung pada pengalamannya, dan berusaha untuk memahami nilai dari tiap orang. Blumer menghindari kuantitatif dan statistik dengan melakukan pendekatan ilmiah melalui riwayat hidup, otobiografi, studi kasus, buku harian, surat, dan nondirective interviews. Penekankan pentingnya ada pada pengamatan peneliti.

Lebih lanjutnya, tradisi Chicago melihat manusia sebagai kreatif, inovatif, dalam situasi yang tak dapat diramalkan. Masyarakat dan diri, dipandang sebagai proses, bukan sebagai struktur untuk membekukan proses atau menghilangkan intisari hubungan sosial. Kedua, mahzab Iowa yang mengambil lebih dari satu pendekatan ilmiah. Tokohnya adalah Manford Kuhn2, salah satu karyanya adalah teknik pengukuran yang terkenal 
dengan sebutan Twenty Statement Self-Attitude Test (konsep pengujian sikap diri melalui dua puluh pertanyaan). Dua di antaranya adalah ordering variable, yaitu menyatakan kepentingan yang relatif menonjol yang dimiliki individu dan locus variable, yaitu menyatakan perluasan tendensi yang secara umum dilakukan individu dalam mengindentifikasi kelompok konsensual.

Penilaian dari tes tersebut adalah dengan meletakkan pernyataan tersebut dalam dua kategori, konsensual dan subkonsensual. Pernyataan dianggap konsensual jika ia mengandung indentifikasi kelas atau golongan; sedangkan jika mengandung indentifikasi yang mengarah ke kualitas tertentu, maka ia merupakan pernyataan subkonsensual3. Kuhn berusaha mengembangkan konsep tentang diri (self) menjadi lebih konkret. Konsep yang lainnya tentang perencanaan tindakan (plan of action) yaitu pola tingkah laku seseorang terhadap objek, karena perencanaan diarahkan oleh sikap, yaitu pernyataan verbal yang menunjukkan nilai tujuan tindakan maka sikap dapat diukur. Konsep diri menyangkut perencanaan tindakan individu terhadap diri meliputi: identitas, kepentingan dan hal yang tidak disukai, tujuan, ideologi, dan evaluasi diri (Basori dan Sukidin 2009).

Interaksi simbolik telah menyatukan studi bagaimana kelompok mengkoordinasi tindakan mereka; bagaimana emosi dipahami dan dikendalikan; bagaimana kenyataan dibangun; bagaimana diri diciptakan; bagaimana struktur sosial besar dibentuk; dan bagaimana kebijakan publik dapat dipengaruhi yang merupakan sebuah gagasan dasar dari perkembangannya dan perluasan teorites Ilmu komunikasi (Dadi Ahmadi, 2008).

\section{Etnometodologi}

Istilah Etnometodologi muncul sebagai istilah yang dicetuskan Garfinkel pada berbagai seminar dan pertemuan American Sociological Association 1954 (Amal 2010). Gagasan-gagasan Garfinkel tersebut menarik banyak perhatian mahasiswa dan kolega Garfinkel lainnya. Pada periode selanjutnya, Garfinkel menyebut Etnometodologi sebagai suatu kajian empiris yang dapat berdiri sendiri dan mandiri .

Perkembangan etnometodologi sebenarnya relative baru bila dibandingkan dengan pendekatan struktural fungsional dan interaksionis-simbolis yang sudah mapan. Pendekatan etnometodologi memiliki ragam yang berbeda, karena subject matternya adalah berbagai jenis perilaku dalam kehidupan sehari-hari sehingga banyak muncul 
kajian lanjutan sesuai dengan disiplin ilmu tertentu. Etnometodologi dengan analisis percakapannya tidak dapat dipungkiri juga memberi pengaruh yang besar dalam agenda penelitian komunikasi. Khususnya menyangkut konsep percakapan sebagai suatu bentuk interaksi.

Orang sering mengira etnometodologi adalah suatu metodologi baru dari etnologi, sering jug dipertukarkan dengan etnografi. Etnometodologi yang diperkenalkan oleh Harold Garfinkel adalah suatu ranah ilmiah yang unik, sekaligus radikal dalam kajian ilmu sosial. Dikatakan radikal karena dikenal keras dalam mengkritik cara-cara yang dilakukan para sosiolog sebelumnya. Garfinkel sepanjang hayatnya memfokuskan mengenai permasalahan-permasalahan konseptual yang menjadi topik utama sosiologi, isu ini ialah mengenai tindakan sosial, hakekat intersubjektivitas dan pembentukkan pengetahuan secara sosial.

Grafinkel mengeksplorasi bidang ini melalui sifat-sifat dasar dan penalaran praktis. Studi ini di maksudkan untuk memisahkan antara teori tindakan dari kesibukan tradisionalyang bergulat dengan masalah motivasi. Garfinkel lalu menyimpulkan bahwa jikalau tindakan-tindakan sosial sehari-hari dibangun di atas premis rasionaliitas ilmiah, maka hasilnya bukan sebuah aktivitas melainkan ketidak aktifan, disorganisasi dan anomi (inactivity, disorganization and anomie). Dengan usulan yang terakhir ini Garfinkel menetapkan sebuah wilayah baru bagi kajian sosial; studi tentang sifat-sifat penalaran akal-sehat praktis dalam situasi tindakan sehari-hari. Usulan ini mengandung penolakan penggunaan rasionalitas ilmiah sebagai titik sentral perbandingan untuk menganalisis penalaran sehari-hari. Studi ini mendorong analis untuk memperkirakan semua komitmen apapun kepada versi tertentu struktur-struktur sosial sebelumnya (termasuk versi yang di pegang analis dan pertisipan sendiri) untuk mendukung penyelidikan tentang bagaimana petisipan menciptakan, merangkai, memproduksi dan memproduksi struktur-struktur sosial yang didalamnya mereka berorientasi. Ini disebut Ethnometodological indifference.

Jadi di lapisan dasarnya studi ini adalah studi tentang penalaran praktis dan tindakan praktis, menahan diri untuk tidak melakukan penilaian yang berefek mendukung atau menolak hal tersebut. Sasaran Etnometodologi adalah deskripsi mendetail tentang praktek-praktek sosial yang terorganisasikan secara alamiah, seperti observasi-observasi di dalam ilmu alam, bias di reproduksi, diperiksa, dievaluasi dan membentuk dasar bagi 
studi dan penyimpulan yang alamiah. Etnometodologi sendiri dalam perdebatan Ilmu Sosial dianggap mengoreksi pandangan-pandangan Parson dalam hal-hal yang bersifat adaptif, dapat dikatakan etnometodologi fleksibel dalam perkembangan fenomenafenomena sosial (Hilber 2012). Dalam komparasinya, jika Parson berpusat pada pemikiran-pemikiran yang bertujuan pada pemecahan "masalah keteraturan tatanan sosial" (problem of social order). Bila Parson berkutat pada struktur, eksperimen-eksperimen Garfinkel memverifikasi empiris terhadap teori-teori Parson yang diderivasi secara analitis.

\section{Phenomenologi}

Pada awalnya, istilah fenomenologi diperkenalkan oleh J.H. Lambert, tahun 1764, untuk menunjuk pada Teori Kebenaran . Setelah itu, istilah ini diperluas pengertiannya. Sedangkan menurut Kockelmans fenomenologi digunakan dalam filsafat pada tahun 1765, yang kadang- kadang ditemukan dalam karya-karya Immanuel Kant, yang kemdian didefinisikan secara baik dan dikonstruksikan sebagai makna secara teknis oleh Hegel. Menurut Hegel, fenomenologi berkaitan dengan pengetahuan yang muncul dalam kesadaran, sains yang mendeskripsikan apa yang dipahami seseorang dalam kesadaran dan pengalamannya.

Fenomenologi dicetuskan secara intens sebagai kajian filsafat pertama kali oleh Edmund Husserl (1859-1938), sehingga Husserl sering dipandang sebagai Bapak Fenomenologi. Filsafatnya sangat populer sekitar tahun 1950-an. Tujuan utama filsafat ini adalah memberi landasan bagi filsafat agar dapat berfungsi sebagai ilmu yang murni dan otonom. Pada awal perekembangannya, fenomenologi merupakan seperangkat pendekatan dalam studi filosofis dan sosiologis, serta studi tentang seni.

Kemunculan fenomenologi oleh Husserl dilatarbelakangi oleh kenyataan terjadinya krisis ilmu pengetahuan. Dalam krisis ini, ilmu pengetahuan tidak bisa memberikan nasihat apa- apa bagi manusia. Ilmu pengetahuan senjang dari praktik hidup sehari-hari. Hal ini, menurut Husserl, konsep teori sejati telah banyak dilupakan oleh banyak disiplin yang maju dalam kebudayaan ilmiah dewasa ini.

Ilmu pengetahuan telah jatuh pada objektivisme, yaitu cara memandang dunia sebagai susunan fakta objektif dengan kaitan- kaitan niscaya. Bagi Husserl, pengetahuan seperti itu berasal dari pengetahuan prailmiah sehari-hari, yang disebut lebenswelt. 
Kesadaran manusia atau subjek ditelan oleh tafsiran-tafsiran objektivistis itu, karena ilmu pengetahuan sama sekali tidak membersihkan diri dari kepentingan-kepentingan dunia kehidupan sehari-hari itu.

Teori yang dihasilkan dari usaha membersihkan pengetahuan dari kepentingankepentingan itu adalah teori sejati yang dipahami tradisi pemikiran Barat. Dengan demikian, menurut Husserl, krisis ilmu pengetahuan itu disebabkan oleh kesalahpahaman disiplin-disiplin ilmiah itu terhadap konsep teori sejati itu. Melalui fenomenologi, Husserl berusaha menemukan hubungan antara teori dengan dunia- kehidupan yang dihayati, yang tujuan akhirnya untuk menghasilkan teori murni yang dapat diterapkan pada praktik. Dengan kata lain, fenomenologi Husserl ini berangkat dari filsafat ilmu. Dalam hal ini, ia mengsusulkan bahwa fenomena-fenomena itu, untuk dipahami, harus didekati dengan cara-cara yang khas.

Edmund Husserl menyatakan bahwa pengetahuan ilmiah sebenarnya telah terpisahkan dari pengalaman sehari-hari dari kegiatan-kegiatan di mana pengalaman dan pengetahuan itu berakar. Maka itu, ia menawarkan fenomenologi. Konsep fenomenologi Husserl dipengaruhi oleh konsep verstehen dari Max We- ber. Verstehen adalah pemahaman. Realitas adalah untuk dipahami, bukan untuk dijelaskan.

Menurut Bertens, apa yang disebut "metode fenomenologi" saat ini kerap kali hampir tidak berkaitan lagi dengan fenomenologi menurut konsepsi Husserl. Ia memahami fenomenologi sebagai suatu analisis deskriptif serta introspektif mengenai kedalaman dari semua bentuk kesadaran dan pengalaman langsung. Fokus filsafat, baginya, adalah lebenswelt (dunia kehidupan) dan erlebnisse (kehidupan subjektif dan batiniah). Bagi Husserl, fenomenologi merupakan kajian filosofis yang melukiskan segala bidang pengalaman manusia. Manusia mengalami pengalaman hidupnya dalam sebuah kesadaran. Baginya, fenomenolgi merupakan sebuah kajian yang tak pernah berakhir, sehingga ia menjuluki dirinya sebagai pemula yang abadi. Oleh karena itu, fenomenologi, kini, telah banyak dikupas, dan diberi penjelasan yang begitu luas dan beragam. Husserl sendiri bercita-cita, fenomenologi menjadi ilmu rigorous, yakni ilmu yang "ketat" yang penjelasannya punya batasan, tidak meragukan. Setiap konsep terdefinisikan dengan jelas.

Husserl mengembangkan sistem filosofis yang berakar dari keterbukaan subjektif, 
sebuah pendekatan radikal terhadap sains yang terus dikritisi. Fenomenologi, bagi Husserl, tak berguna bagi mereka yang berpikiran tertutup. Seorang fenomenolog adalah orang yang terbuka pada realitas dengan segala kemungkinan rangkaian makna di baliknya, tanpa tendensi mengevaluasi atau menghukumi.

Fenomenologi Husserl, menurut Bertens, pada akhirnya berdimensi sejarah. Suatu fenomena tidaklah sebagai sesuatu yang statis, tetapi dinamis. Fenomena itu memiliki sejarah. Sejarah berkaitan dengan riwayat individual manusia, juga manusia secara keseluruhan. Kesadaran kita mengalami perkembangan; sejarah kita selalu hadir dalam cara kita menghadapi realitas. Setiap fenomena mengandung muatan sejarah. Suatu fenomena tidak beridiri sendiri, tetapi memiliki kaitan dengan peristiwa-peristiwa sebelumnya. Setelah Husserl, fenomenologi berkembang,

antara lain, dalam pemikiran Morleau-Ponty, Alfred Schutz, Peter L. Berger, dan Thomas Luckmann. Pandangan Husserl berbeda dengan padangan para fenomenolog berikutnya. Bagi Husserl, pengalaman merupakan sesuatu yang bersifat objektif, terpisahkan dari individu.

Maurice Morleau-Ponty banyak dipengaruhi pemikiran Husserl. Tetapi, ia menolak idealisme Husserl. Bagi Morleau-Ponty, manusia adalah kesatuan dari dimensi fisik dan nonfisik yang menciptakan makna dalam dunia. Seseorang, sebagai subjek pengamat, memiliki relasi dengan sesuatu di dunia ini. Ia dipengaruhi oleh dunia dan pada gilirannya ia pun memaknai dunia itu.

Dunia yang kita alami merupakan hasil ciptaan kesadaran kita. Fenomenologi memang mengakui adanya realitas eksternal sebagai hal yang benar- benar ada, tetapi hal ituhanya bisa dipahami melalui kesadaran yang kita miliki.

Menurut Alfred Schutz, proses pemaknaan diawali dengan proses penginderaan, suatu proses pengalaman yang terus berikesinambungan. Arus pengalaman inderawi ini, pada awalnya, tidak memiliki makna. Makna munculketika dihubungkan dengan pengalaman-pengalaman sebelumnya serta melalui proses interaksi dengan orang lain. Karena itu, ada makna individual, dan ada pula makna kolektif tentang sebuah fenomena. Kesadaran kita memproses data inderawi. Bagi Schutz, tindakan manusia selalu punya makna menurut Weber makna itu identik dengan motif tindakan. Namun, makna itu tidak ada yang bersifat aktual dalam kehidupan. 
Lebih jauh, Peter L. Berger dan Thomas Luckmann menyatakan bahwa manusia mengonstruksi realitas sosial melalui proses subjektif, tetapi dapat berubah menjadi objektif. Proses konstruksi terjadi melalui pembiasaan di antara para aktor. Hubungan antarindividu dengan institusi terjadi secara dialektik. "Masyarakat adalah produk manusia, masyarakat adalah realitas objektif, dan manusia produk masyarakat." Proses itu terjadi melalui hubungan memori dari pengalaman dan peran individu. Manusia adalah produk dari masyarakat yang diciptakannya sendiri. Selain itu, fenomenologi berfokus pada pengalaman personal, termasuk bagaimana para individu mengalami satu sama lain. Oleh karena itu, komunikasi dipandang sebagai hubungan antarpribadi secara bersama melalui dialog (Hasbiansyah, 2009).

\section{Aplikasi}

Aplikasi atau yang sering disebut dengan Pengumpulan data merupakan salah satu tahapan sangat penting dalam penelitian. Teknik pengumpulan data yang benar akan menghasilkan data yang memiliki kredibilitas tinggi, dan sebaliknya. Oleh karena itu, tahap ini tidak boleh salah dan harus dilakukan dengan cermat sesuai prosedur dan ciri-ciri penelitian kualitatif (sebagaimana telah dibahas pada materi sebelumnya). Sebab, kesalahan atau ketidaksempurnaan dalam metode pengumpulan data akan berakibat fatal, yakni berupa data yang tidak credible, sehingga hasil penelitiannya tidak bisa dipertanggungjawabkan. Hasil penelitian demikian sangat berbahaya, lebih-lebih jika dipakai sebagai dasar pertimbangan untuk mengambil kebijakan public (Burhan Bungin, 2010).

Misalnya, jika peneliti ingin memperoleh informasi mengenai persepsi guru terhadap kurikulum yang baru, maka teknik yang dipakai ialah wawancara, bukan observasi. Sedangkan jika peneliti ingin mengetahui bagaimana guru menciptakan suasana kelas yang hidup, maka teknik yang dipakai adalah observasi. Begitu juga jika, ingin diketahui mengenai kompetensi siswa dalam matapelajaran tertentu, maka teknik yang dipakai adalah tes, atau bisa juga dokumen berupa hasil ujian. Dengan demikian, informasi yang ingin diperoleh menentukan jenis teknik yang dipakai (materials determine a means). Itu pun masih ditambah dengan kecakapan peneliti menggunakan teknik-teknik tersebut. Bisa saja terjadi karena belum berpegalaman atau belum memiliki pengetahuan yang memadai, peneliti tidak berhasil menggali informasi yang dalam, sebagaimana karakteristik data dalam penelitian kualitatif, karena kurang cakap 
menggunakan teknik tersebut, walaupun teknik yang dipilih sudah tepat. Solusinya terus belajar dan membaca hasil-hasil penelitian sebelumnya yang sejenis akan sangat membantu menambah kecakapan peneliti.

Penggunaan istilah 'data' sebenarnya meminjam istilah yang lazim dipakai dalam metode penelitian kuantitatif yang biasanya berupa tabel angka. Namun, di dalam metode penelitian kualitatif yang dimaksudkan dengan data adalah segala informasi baik lisan maupun tulis, bahkan bisa berupa gambar atau foto, yang berkontribusi untuk menjawab masalah penelitian sebagaimana dinyatakan di dalam rumusan masalah atau fokus penelitian (Afrizal, 2014).

Di dalam metode penelitian kualitatif, lazimnya data dikumpulkan dengan beberapa teknik pengumpulan data kualitatif, yaitu; 1). wawancara, 2). observasi, 3). dokumentasi, dan 4). diskusi terfokus (Focus Group Discussion). Sebelum masing-masing teknik tersebut diuraikan secara rinci, perlu ditegaskan di sini bahwa hal sangat penting yang harus dipahami oleh setiap peneliti adalah alasan mengapa masing-masing teknik tersebut dipakai, untuk memperoleh informasi apa, dan pada bagian fokus masalah mana yang memerlukan teknik wawancara, mana yang memerlukan teknik observasi, mana yang harus kedua-duanya dilakukan, dan sebagainya. Pilihan teknik sangat tergantung pada jenis informasi yang diperoleh (Burhan Bungin, 2013).

1. Wawancara

Wawancara merupakan proses komunikasi atau interaksi untuk mengumpulkan informasi dengan cara tanya jawab antara peneliti dengan informan atau subjek penelitian. Dengan kemajuan teknologi informasi seperti saat ini, wawancara bisa saja dilakukan tanpa tatap muka, yakni melalui media telekomunikasi. Pada hakikatnya wawancara merupakan kegiatan untuk memperoleh informasi secara mendalam tentang sebuah isu atau tema yang diangkat dalam penelitian. Atau, merupakan proses pembuktian terhadap informasi atau keterangan yang telah diperoleh lewat teknik yang lain sebelumnya.

Karena merupakan proses pembuktian, maka bisa saja hasil wawancara sesuai atau berbeda dengan informasi yang telah diperoleh sebelumnya. Agar wawancara efektif, maka terdapat berapa tahapan yang harus dilalui, yakni : a). mengenalkan diri, b). menjelaskan maksud kedatangan, c). menjelaskan materi wawancara, dan d). mengajukan pertanyaan (Yunus, 2010).

Selain itu, agar informan dapat menyampaikan informasi yang komprehensif sebagaimana diharapkan peneliti, maka berdasarkan pengalaman wawancara yang 
penulis lakukan terdapat beberapa kiat sebagai berikut : a). ciptakan suasana wawancara yang kondusif dan tidak tegang, b). cari waktu dan tempat yang telah disepakati dengan informan, c). mulai pertanyaan dari hal-hal sederhana hingga ke yang serius, d). bersikap hormat dan ramah terhadap informan, e). tidak menyangkal informasi yang diberikan informan, f). tidak menanyakan hal-hal yang bersifat pribadi yang tidak ada hubungannya dengan masalah/tema penelitian, g). tidak bersifat menggurui terhadap informan, h). tidak menanyakan hal-hal yang membuat informan tersinggung atau marah, dan i). sebaiknya dilakukan secara sendiri, j) ucapkan terima kasih setelah wawancara selesai dan minta disediakan waktu lagi jika ada informasi yang belum lengkap.

Setidaknya, terdapat dua jenis wawancara, yakni: a). wawancara mendalam (indepth interview), di mana peneliti menggali informasi secara mendalam dengan cara terlibat langsung dengan kehidupan informan dan bertanya jawab secara bebas tanpa pedoman pertanyaan yang disiapkan sebelumnya sehingga suasananya hidup, dan dilakukan berkali-kali; b). wawancara terarah (guided interview) di mana peneliti menanyakan kepada informan hal-hal yang telah disiapkan sebelumnya. Berbeda dengan wawancara mendalam, wawancara terarah memiliki kelemahan, yakni suasana tidak hidup, karena peneliti terikat dengan pertanyaan yang telah disiapkan sebelumnya. Sering terjadi pewawancara atau peneliti lebih memperhatikan daftar pertanyaan yang diajukan daripada bertatap muka dengan informan, sehingga suasana terasa kaku.

Dalam praktik sering juga terjadi jawaban informan tidak jelas atau kurang memuaskan. Jika ini terjadi, maka peneliti bisa mengajukan pertanyaan lagi secara lebih spesifik. Selain kurang jelas, ditemui pula informan menjawab "tidak tahu". Menurut Singarimbun dan Sofian Effendi, jika terjadi jawaban "tidak tahu", maka peneliti harus berhati-hati dan tidak lekas-lekas pindah ke pertanyaan lain. Sebab, makna "tidak tahu" mengandung beberapa arti, yaitu:

a. Informan memang tidak mengerti pertanyaan peneliti, sehingga untuk menghindari jawaban "tidak mengerti", dia menjawab "tidak tahu”.

b. Informan sebenarnya sedang berpikir memberikan jawaban, tetapi karena suasana tidak nyaman dia menjawab "tidak tahu".

c. Pertanyaannya bersifat personal yang mengganggu privasi informan, sehingga jawaban 'tidak tahu' dianggap lebih aman 
d. Informan memang betul-betul tidak tahu jawaban atas pertanyaan yang diajukan. Karena itu, jawaban "tidak tahu" merupakan jawaban sebagai data penelitian yang benar dan sungguh yang perlu dipertimbangkan oleh peneliti.

2. Observasi

Selain wawancara, observasi juga merupakan salah satu teknik pengumpulan data yang sangat lazim dalam metode penelitian kualitatif. Observasi hakikatnya merupakan kegiatan dengan menggunakan pancaindera, bisa penglihatan, penciuman, pendengaran, untuk memperoleh informasi yang diperlukan untuk menjawab masalah penelitian. Hasil observasi berupa aktivitas, kejadian, peristiwa, objek, kondisi atau suasana tertentu, dan perasaan emosi seseorang. Observasi dilakukan untuk memperoleh gambaran riil suatu peristiwa atau kejadian untuk menjawab pertanyaan penelitian.

Bungin mengemukakan beberapa bentuk observasi, yaitu: a). Observasi partisipasi, b). observasi tidak terstruktur, dan c). observasi kelompok. Berikut penjelasannya:

a. Observasi partisipasi adalah (participant observation) adalah metode pengumpulan data yang digunakan untuk menghimpun data penelitian melalui pengamatan dan penginderaan di mana peneliti terlibat dalam keseharian informan.

b. Observasi tidak terstruktur ialah pengamatan yang dilakukan tanpa menggunakan pedoman observasi, sehingga peneliti mengembangkan pengamatannya berdasarkan perkembangan yang terjadi di lapangan.

c. Observasi kelompok ialah pengamatan yang dilakukan oleh sekelompok tim peneliti terhadap sebuah isu yang diangkat menjadi objek penelitian.

\section{Dokumen}

Selain melalui wawancara dan observasi, informasi juga bisa diperoleh lewat fakta yang tersimpan dalam bentuk surat, catatan harian, arsip foto, hasil rapat, cenderamata, jurnal kegiatan dan sebagainya. Data berupa dokumen seperti ini bisa dipakai untuk menggali infromasi yang terjadi di masa silam. Peneliti perlu memiliki kepekaan teoretik untuk memaknai semua dokumen tersebut sehingga tidak sekadar 
barang yang tidak bermakna.

4. Focus Group Discussion

Metode terakhir untuk mengumpulkan data ialah lewat Diskusi terpusat (Focus Group Discussion), yaitu upaya menemukan makna sebuah isu oleh sekelompok orang lewat diskusi untuk menghindari diri pemaknaan yang salah oleh seorang peneliti. Misalnya, sekelompok peneliti mendiskusikan hasil UN 2011 di mana nilai rata-rata siswa pada matapelajaran bahasa Indonesia rendah. Untuk menghindari pemaknaan secara subjektif oleh seorang peneliti, maka dibentuk kelompok diskusi terdiri atas beberapa orang peneliti. Dengan beberapa orang mengkaji sebuah isu diharapkan akan diperoleh hasil pemaknaan yang lebih objektif.

\section{DAFTAR PUSTAKA}


Afrizal, (2014). Metode Penelitian Kualitatif : sebuah upaya mendukung penggunaan penelitian kualitatif dalam berbagai disiplin ilmu. Cet. 1;Jakarta; Rajawali Pers : 150

Amal, M. K. (2010). Etnometodologi Anatomi dan Perkembangan Teori Sosial. Malang: Aditya Media

Anantawikrama Tungga Atmadja. (2013).Pergulatan Metodologi Dan Penelitian Kualitatif Dalam Ranah Ilmu Akuntansi, Jurnal Akuntansi Profesi Vol. 3 No.2

Bachtiar S. Bachri. (2010). Meyakinkan Validitas Data Melalui Triangulasi Pada Penelitian Kualitatif , Jurnal Teknologi Pendidikan, Vol.10 No. 1

Basrowi dan Sukidin. (2002). Metode Penelitian Kualitatif Perspektif Mikro. Surabaya: Insan Cendekia

Burhan Bungin. (2009). Penelitian Kualitatif: Komunikasi, Ekonomi, Kebijakan Publik, dan Ilmu Sosial Lainnya. Jakarta: Kencana Prenada Media Group.

Burhan Bungin, (2013). Metedologi penelitian social dan ekonomi, Jakarta, Prenemadia Group:. 133

Chariri A.(2009). Landasan Filsafat dan Metode Penelitian Kualitatif

Dadi Ahmadi. (2009). Interaksi Simbolik: Suatu Pengantar Mediator, Vol. 10, No. 02

Dawam Raharjo. (2009). Islam dan Transformasi Sosial-Ekonomi, Lembaga Studi Agama dan Filsafat, Jakarta $: 14$

Emzir (2010). Metodologi Penelitian Kualitatif: Analisis Data, Cetakan ke-1. PT. Raja Grafindo. Jakarta.

George Ritzer. (2009). Sosiologi Ilmu Pengetahuan Berparadigma Ganda, Terjemahan Alimandan, PT. RajaGrafindo Perkasa, Jakarta : 7

Hasbiyansyah. (2009). Pendekatan Fenomenologi: Pengantar Praktik Penelitian dalam Ilmu Sosial dan Komunikasi, Mediator Vol. 9, No.1 
Hilber, R.A. (2012). Etnometodologi dan Teori Sosial. In Turner, B.S. Teori Sosial dari Klasik sampai Postmodern.Yogyakarta: Pustaka Pelajar

Ihwan Susila. (2015). Pendekatan Kualitatif Untuk Riset Pemasaran Dan Pengukuran Kinerja Bisnis, Benefit Jurnal Manajemen dan Bisnis, Vol :19, No: 1 : 12-23

Jujun Suriasumantri. (2010). Filsafat Ilmu, sebuah pengantar popular. Pustaka Sinar Harapan, Jakarta : 105

Lukas S. Musianto. (2010).Perbedaan Pendekatan Kuantitatif dengan Pendekatan Kualitatif dalam Metode Penelitian, Jurnal Manajemen \& Kewirausahaan Vol. 4, No. 2 : 123 - 136

Mohammad Mulyadi. (2011). Penelitian Kuantitatif Dan Kualitatif Serta Pemikiran Dasar Menggabungkannya, Jurnal Studi Komunikasi Dan Media Vol. 15 No. 1 : 52

Nimas Eki Suprawati. (2009). Pendekatan Kuantitatif Dan Kualitatif Filsafat Ilmu Untuk Penelitian Psikologi, Jurnal Orientasi Baru, Vol. 18 No. 2

Noeng Muhajir. (2009). Metodologi Penelitian Kualitatif, Rake Sarasin, Yogyakarta : 4

Sulaiman. (2018). Paradigma dalam Penelitian Hukum, Kanun Jurnal Ilmu Hukum,Vol.20, No.2

Yunus, Hadi Sabari. (2010). Metodologi Penelitian Wilayah Kontemporer. Yogyakarta: Pustaka Pelajar : 385 